\title{
The Extraordinary Mediocrity of the Holocene
}

\author{
B. Lee Drake ${ }^{1}$
}

1. Department of Anthropology, University of New Mexico.

\begin{abstract}
The extinction of multiple genera of large-bodied mammals during the Holocene interglacial transition has been attributed to three hypothesized causes: human migration, climate change, and an extra-terrestrial impact. Two of these hypotheses, climate change and extra-terrestrial impactor, would predict that the Holocene interglacial transition was uniquely stressful for large-bodied mammals. To test the severity of the Holocene interglacial transition relative to other warming events, ice cores from Antarctica were analyzed using Bayesian change-point analysis and modeling. Most features of the Holocene could be predicted by a loess model of previous interglacials with a span of 0.015. The Younger Dryas, a punctuated return to cold temperatures, also had precedent in previous interglacials and interstadials. The Holocene lacks any extreme in either temperature anomaly or temperature change, and fails to provide any evidence for extreme climatic changes that would have been uniquely stressful to Earth's biota.
\end{abstract}




\section{Introduction}

From 18,000 to 10,000 cal yr before present (BP), 37 genera of animals in North America, 51 genera in South America, 49 genera in Eurasia, and 29 in Africa went extinct (Sandom et al 2014). These extinction events occurred synchronously (Faith and Surovell et al. 2009). Earlier, around 50,000 cal yr BP, 21 genera went extinct in Australia. These extinctions were concentrated overwhelmingly in large megafauna with a mass of over 1,000 kg (Koch and Barnosky 2006); extinctions of smaller taxa did not approach this scale. Within the same time span on all continents, modern humans (Homo sapiens sapiens) expanded across multiple ecological niches. These ecological changes, paired with the stabilization of climate following the last interglacial transition, mark the transition from the Pleistocene to the Holocene.

This biotic turnover in the Holocene has led to its proposal as the sixth major extinction, making it comparable to past cataclysms, such as the K-Pg extinction that led to the disappearance of all non-avian dinosaur taxa. There are three major hypotheses explaining the cause of the collapse and transformation of biotic systems during the Holocene:
a) Climatic changes since the Last Glacial Maximum (c. 26,000 - 19,000 BP)
b) Ecosystem shocks related to the dispersal of Homo sapiens sapiens
c) Extra-terrestrial impacts causing far reaching climatic and environmental damage

Two of these hypotheses (climate and extra-terrestrial impacts) would predict extra-ordinary conditions associated with the last interglacial transition and the Holocene; the comet hypothesis predicts extraordinary changes at 12,700 cal yr BP, while the climate hypotheses predict unique changes in a broader interval (c. 18,000 to 8,000 cal yr BP). The present study tests predictions that the Holocene interglacial and its transition relative to past interglacials were unique. 


\section{Climatic Background}

To understand the the Holocene and it's interglacial dynamics, it is necessary to place it in context of the Pleistocene. For the past 2.53 million years, the Earth has oscillated between extended glacial periods and brief warming intervals known as interglacials. These cycles are the products

of three astronomical events: orbital shape (eccentricity), axial tilt (obliquely) and axial precession: collectively they are known as Milankovitch Cycles. Of these three forces, orbital shape (eccentricity) has been dominant for the measurable record of ice cores (Hayes et al. 1976; AbeOuchi et al 2013). Due to the unique position of the North American and Eurasian continental plates, decreases in solar insulation related to subtle shifts in Earth's orbit cause ice sheets to expand south (Abe-Ouchi et al. 2013). Conversely, increasing solar insulation leads to retreating ice sheets (Kawamura et al. 2007). The size of ice sheets in the Northern Hemisphere affects ocean current circulation, creating a feedback loop that can lead to long periods of cold temperatures (Dokken and Jansen 1999) punctuated by rapid warming or freezing (Clark et al. 1999; Menviel et al. 2011). While the Milankovitch cycles drive the pattern of glacials and interglacials, it is the melt of glaciers and their subsequent freshwater intrusions into the thermohaline circulation that affect the rapidity of punctuated climate shifts during interglacial transitions. The dramatic impacts of climatic changes on wildlife are most often attributed to these freshwater intrusion events.

Interglacials, such as the Holocene or the Eemian, are typified by temperature increases which lead to the retreat of ice sheets. The Eemian in particular was warmer than the Holocene, as evidence by ice core (NEEM 2013) and pollen (Kaspar et al. 2005) records. The Greenland ice sheet retreated further than its present location (Otto-Bliesner et al. 2006), and even supported forests on its southern margins (Willerslev et al. 2007). Increased glacial melt (Cuffey and Marshall 2000, Dutton and Lambeck 2012) and thermal expansion of sea water (McKay et al. 2011) led to 
sea levels at least $6.6 \mathrm{~m}$ higher compared to those of the Holocene (Kopp et al. 2009). Despite the warmer temperatures and arid episodes (Sirocko et al. 2005), medium-sized mammals such as deer and large-sized proboscideans thrived in Europe (van Kolfschoten 2000). This illustrates that while interglacials were markedly warmer than the glacial periods which dominate the Pleistocene, they were not necessarily drivers of mass extinction prior to the Holocene.

While interglacials may feature stable temperatures, their transitions can be marked by dramatic and punctuated climatic shifts. During the Holocene interglacial transition, a short-lived climatic reversal known as the Younger Dryas occurred between c. 12,900 to 11,700 BP. The Younger Dryas was a period of much colder and arid temperatures in Europe. It was likely caused when cold freshwater from glacial melt in North America temporarily reversed the Gulf Stream (Keigwin et al. 1991; Rühlemann et al. 1999; McManus et al. 2004; Broecker 2006). Many hypothesize that these freshwater release events during glacial cycles are frequent climate forces (McCabe and and Clark 1998; Clark et al. 2002; McManus et al. 2004), and are important in creating stadial conditions (Liu et al. 2009).

Following the Younger Dryas, the early Holocene was typified by drier, arid conditions known as the Altithermal (c. 10,000 to 8,000 cal year BP) (Antevs 1948, Holliday 2000) and Holocene Thermal Maximum (HTM) (Kaplan and Wolfe 2006). This Holocene interglacial following the Younger Dryas has been one of remarkable climatic stability (Richerson et al. 2001). While there have been short-lived climatic episodes, such as the 8.2 kya event that is likely a smaller-scale freshwater melt pulse into the North Atlantic (Alley et al. 1997; Alley and Ágústsdóttir 2005), overall variation is at least $2{ }^{\circ} \mathrm{C}$ degrees lower than in the preceding deglaciation period, the Eemian.

\section{Climatic Extinction Hypothesis Background}


The extinction of the megafauna was associated with the rapidly warming climate of the most recent interglacial transition preceding the Holocene. The warming of the interglacial featured severe aridity in some areas during the Bølling-Allerød period, which lasted from c. 14,700 to 12,900 BP. This aridity has been invoked as a potential cause of the megafauna extinctions (Polyak et al. 2012). Punctuated climatic shifts throughout the last glacial maximum to the Younger Dryas identified in the GISP2 ice core record align with the last occurrence of some species in the fossil record (Cooper et al. 2015). Considering megafauna extinctions on a taxon level (Grayson 2007), the environmental impacts of the shift to interglacial conditions differed by region and taxa. The replacement of herbaceous vegetation by shrubs and trees in Siberia is hypothesized to be the cause of Coelodonta antiquarius in north-eastern Siberia (Stuart and Lister 2012). Similar vegetation changes are suggested for the extinction of megafauna in the Japanese archipelago (Iwase et al. 2012). The extinction of Mammuthus primogensis in Northern Europe is attributed to reforestation during the Younger Dryas (Ukkonen et al. 2011, Nadachowski et al. 2011).The specific driver of mammoth extinctions in particular is suggested to be linked to unique rapid climate change (Metcalfe et al. 2011):

Modern elephants rely on knowledge of food and water sources gained through experience and passed on over generations. On the basis of the consistency in seasonal patterns among Clovis mammoths, they probably had little or no preceding experience with such a drastic change in climatic conditions within their lifetimes, making it potentially difficult for them to adapt.

There are differing arguments for unique variables for the Holocene Interglacial Transition. Megafaunal extinctions in the arctic have been attributed to a "uniquely fatal" combination of declining range quality and flooding of the Bering Straight (Mann et al. 2015). In North America at large, changes in nitrogen sinks are postulated as a unique variable (Faith 2011), though data for 
prior interglacials is not included. In the southern hemisphere, arguments for megafaunal extinctions in Brazil being caused by unique changes during the Holocene interglacial transition compared to previous Pleistocene interglacials are suggested for megafaunal extinctions in Brazil (Hubbe et al. 2013), though the nature of these unique changes is not specified.

\section{Impact Extinction Hypothesis Background}

Around the time of the Younger Dryas, some suggest the Earth was impacted by a comet (ex: Firestone et al. 2007). Shocked quartz, carbon-rich microspherules, nanodiamonds, and elevated concentrations of platinum-group elements has been proposed as evidence for this impact (Kennett et al. 2009; Malhaney et al. 2010; Firestone et al. 2011; Israda-Alcántara et al. 2011). Elevated platinum is also present in the GISP2 ice core (Petaev et al. 2013). The hypothesized impact would have had severe consequences; it is argued to have deposited 10,000 tons of debris (Wittke et al. 2013) and have caused mass wildfires among other catastrophic ecological effects (Kennett et al. 2008). Most central to this paper is the proposed climatic effects; the hypothetical impact is suggested to have been a central cause of the Younger Dryas (Firestone et al 2007; Kennett et al. 2015).

The impact hypothesis remains controversial; many of the geochemical indicators for an impact may simply be normal byproducts of wetland ecosystems (Pigati et al. 2012) or otherwise nondiagnostic of impacts (French and Koeberl 2010). Attempts at replication in identifying geochemical evidence have not always been successful (Surovell et al. 2009; Holliday et al. 2016). There are additional problems with the underlying argument; the lack of an impact craters is attributed to the initial impact being on a glacial ice sheet, yet shocked quartz arising from an impact on Earth's crust is still invoked as evidence in other areas. 


\section{Study Design}

Both the known megafauna extinctions and the hypothesized comet impact are predicated on the same assumption: climatic variations during the Holocene Interglacial transition were particularly severe and drove multiple large-bodied mammal taxa to extinction. However, much of the evidence for aridity or other severe climatic changes have relied on records from the past 70,000 years. As such, it lacks comparison to previous interglacials. To fully understand the nature of the Holocene Interglacial transition, it is necessary to compare records that extend back to past interglacials to determine if the Holocene was truly a unique event. As an example, Polyak et al. (2012) argue that a severe centuries-long drought led to extinctions of megafauna in the US Southwest during the Bølling-Allerød period 15,000 years ago, yet Fawcett et al. (2011) find that severe multi-century droughts have occurred repeatedly in the region over the past 560,000 years. The necessary criterion for determining whether or not climate change contributed to the extinction of a particular taxon is identifying that such a climatic event is unique (or uniquely severe) in that taxon's history.

The present study evaluates the climate-based mega faunal extinction hypothesis by evaluating ice core records that span the late Pleistocene. These include the Vostok cores (Petit et al. 1999) and the European Project for Ice Coring in Antarctica (EPICA) Dome C core (EPICA community members 2004). While it is well demonstrated that climatic conditions during the glacialHolocene transition were severe, it is not clear whether they were greater in magnitude or rapidity relative to past glacial-interglacial transitions. By contrasting the Holocene transition with the most recent past interglacial conditions, a relative statement on severity can be made.

Two hypotheses can be generated regarding the Holocene interglacial: 
$\mathrm{H}_{0}$ : There is no difference in temperature anomalies for the Holocene relative to past interglacials/ interstadials

$H_{a}$ : The Holocene interglacial was a period of uniquely variable temperature fluctuations relative to past interglacials/interstadials

To test these hypotheses, it is necessary to evaluate the Holocene relative to past interglacials and interglacial transitions.

\section{Method:}

Past interglacial periods were defined as continuous temperature anomalies above or near $0{ }^{\circ} \mathrm{C}$ (e.g. equal to warmer relative to the Holocene). Past interglacial transitions were defined as a continuous rise in temperature anomalies from $-8^{\circ} \mathrm{C}$ to $0{ }^{\circ} \mathrm{C}$. The termination of an interglacial period was determine by identifying the point when temperature anomalies fell systematically below $1{ }^{\circ} \mathrm{C}$. While a distinction is recognized between interglacial (e.g. periods of high temperatures that last more than 10,000 years) and interstadials (e.g. periods of high temperatures that last for less than 10,000 years), what is important to this analysis is the rate of temperature increases during warming events, not their duration. Alignment was checked against a Bayesian change point model using a prior probability of $0.001,2,000$ burn-ins, and 10,000 markov-chain Monte Carlo re-simulations of the data (Barry and Hartigan 1993; Erdman and Emmerson 2007).

While ice core data from both EPICA Dome C and Vostok clearly indicate a regular pattern of interglacials and interstadials (Figure 1), only the Holocene and Eemian are well defined chronologically and climatically. For the purposes of this paper, the terminology of Yarmouth will be used generally for pre-Eemian interglacials shared between the cores. While the terminology is 
inconsistent with past geological definitions (Hallberg et al. 1980; Hallberg 1986), it is still chronologically appropriate and provides a reference point for interpreting ice core data.

For qualitative comparison of the data, smoothed mean averages were taken of the data relative to the data's resolution. This was done using double exponential moving average with a smoothing ratio of $\frac{2}{(n+1)}$, where $\mathrm{n}$ is the number of data observations for each interglacial/interstadial divided by the duration of the interglacial/interstadial.

To model a typical Late Pleistocene interglacial, a generalized model was built using a loess curve from the four previous interglacials (The Eemian and Yarmouth I, II) and one interstadial (Yarmouth III) with a span of 0.015 . This was used to create a reference comparison for climatic variations during the Holocene interglacial transition.

\section{Results}




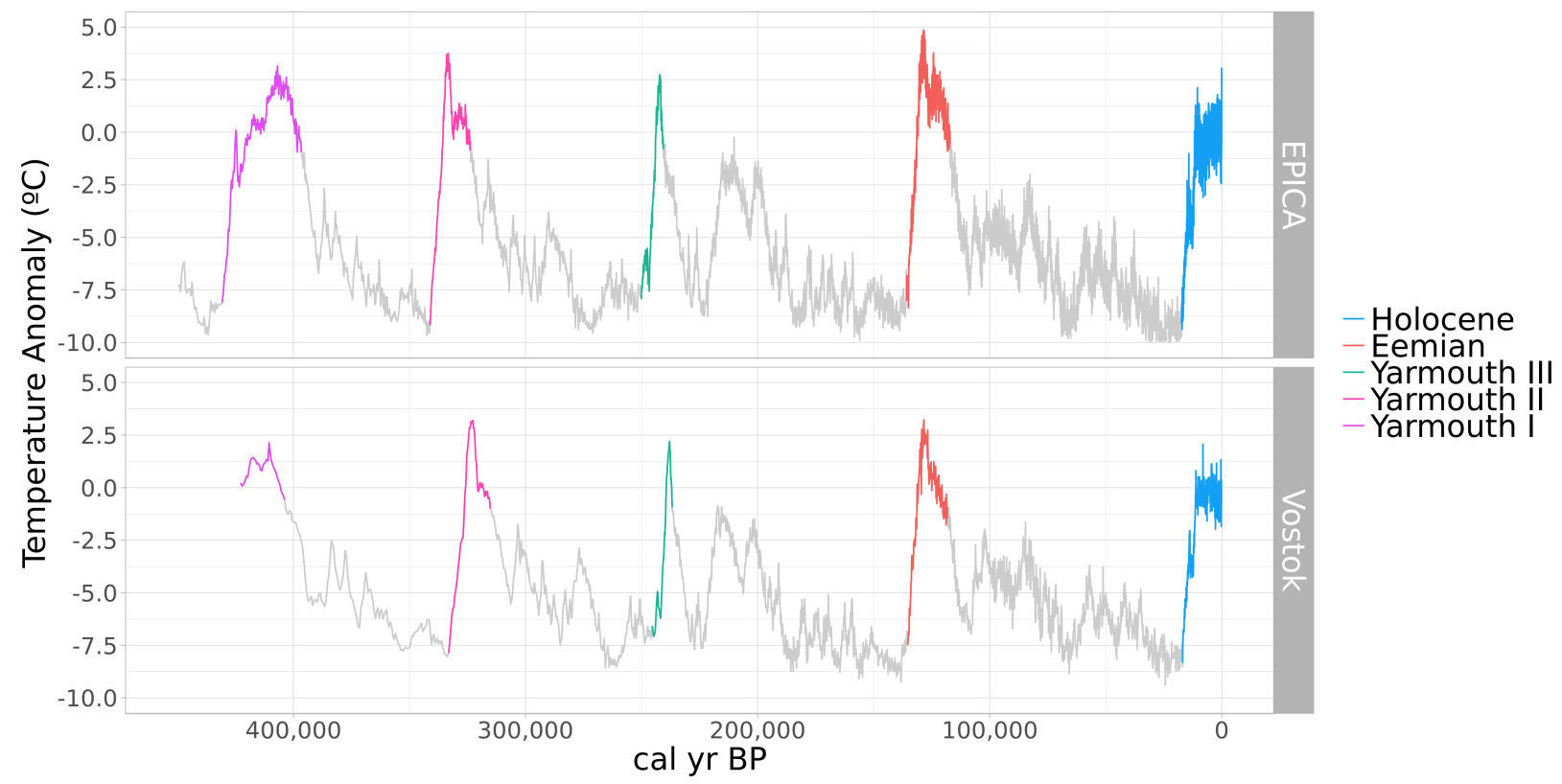

Figure 1: Most recent 5 interglacial/interstadial periods and their transitions from EPICA and Vostok. 

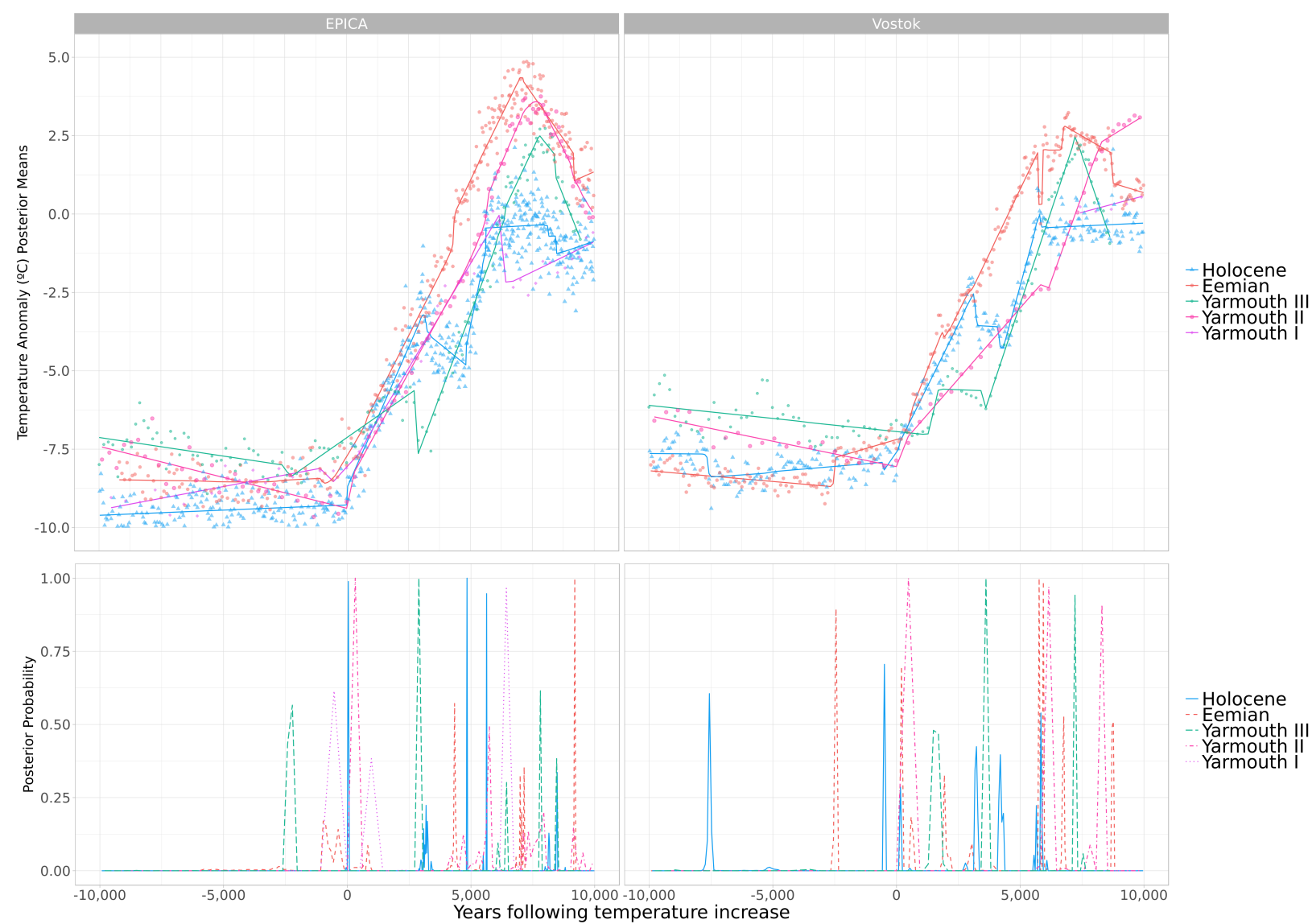

\section{- Holocene} Eemian

Yarmouth

Yarmouth I

Figure 2: Bayesian change point analysis of interglacial/interstadial transitions. 


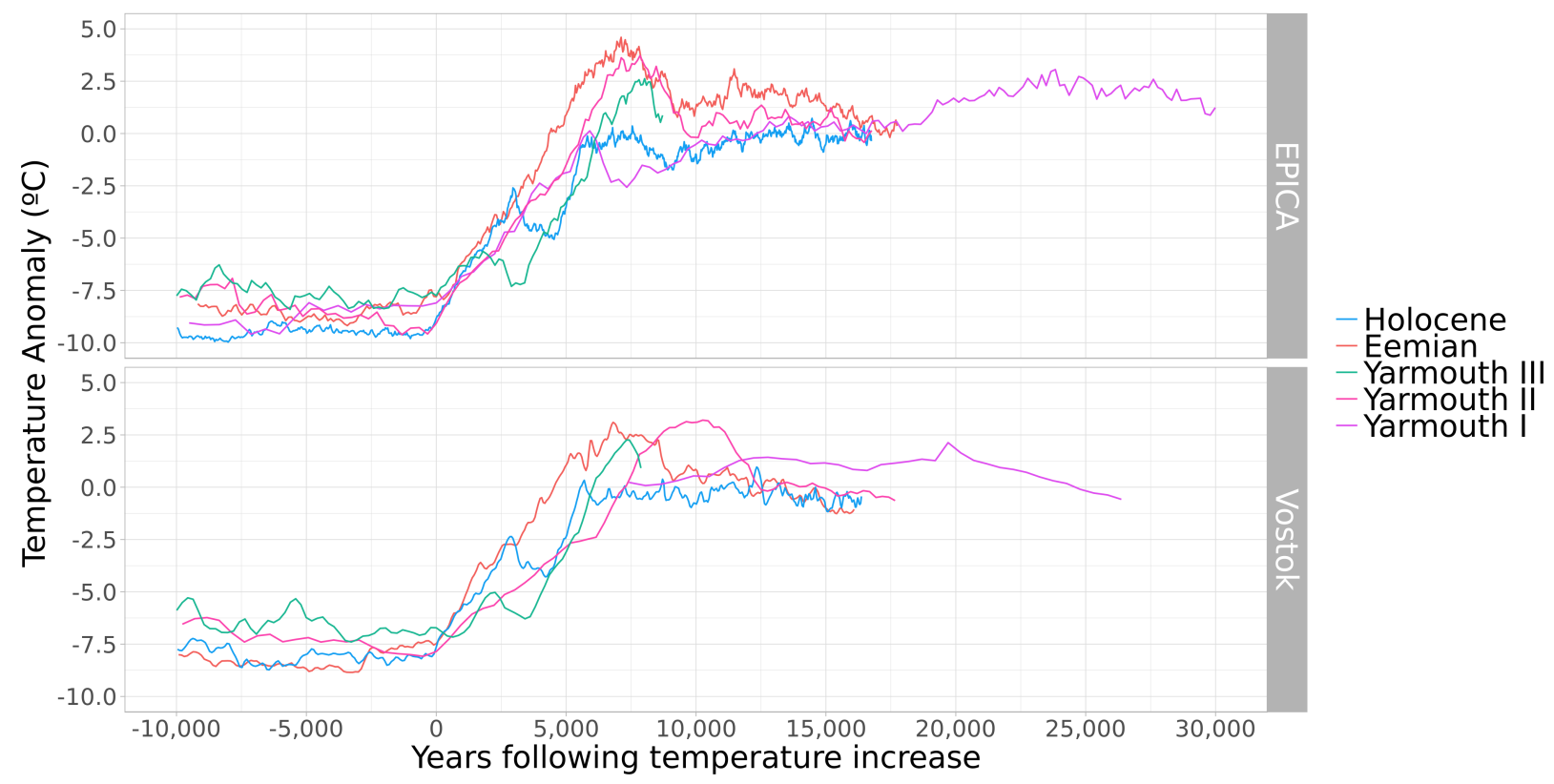

Figure 3: Comparison of interglacial/interstadial periods and their transitions; data was smoothed proportional to the number of data points present

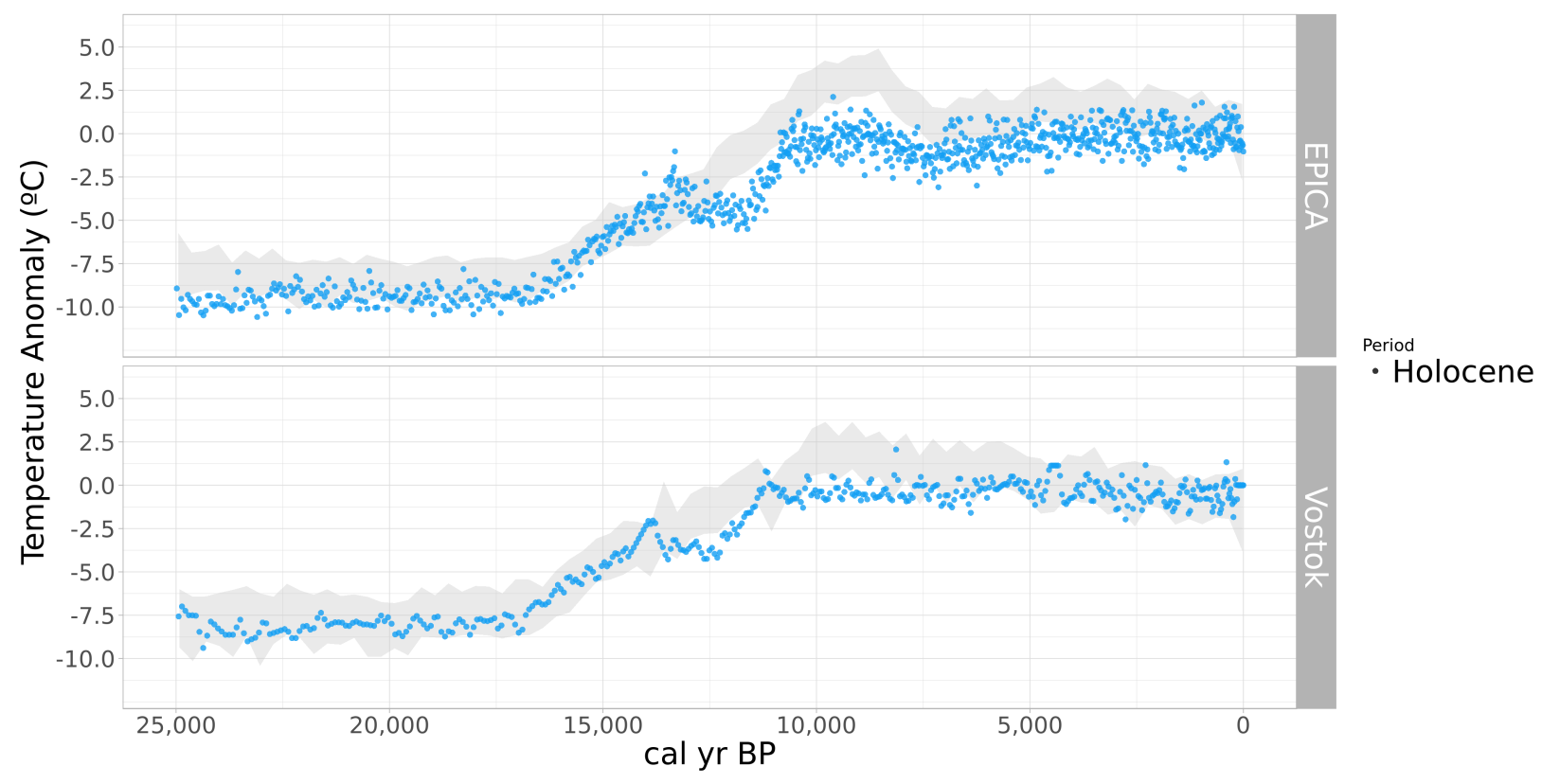

Figure 4: The Holocene compared to a generalized loess model of the previous 4 interglacials. 
The Holocene interglacial is not the warmest period relative to past interglacials, with the brief exception of the very peak of the Bølling-Ållerød interstadial (Figure 3, Figure 4). All interglacials had higher temperature anomaly maxima than the Holocene in both the EPICA and Vostok records, with the possible exception of only briefly before the Younger Dryas in the Vostok record.

The temperature fluctuations associated with the Younger Dryas fall within or near variability of previous interglacials in the EPICA and Vostok ice cores (Figure 4). Interestingly, a temperature reversal it is not unique to the Younger Dryas; Yarmouth III had a more severe temperature reversal 5,000 years after warming began (Figure 3). Not only was the Yarmouth III reversal colder at its minima by $5{ }^{\circ} \mathrm{C}$, but the temperature increase following it was both steeper and led to $2.5^{\circ} \mathrm{C}$ warmer temperatures relative to today. Otherwise, it had a similar duration and was timed at almost the same time in the glacial cycle.

The Holocene does appear to have lower interglacial temperatures in general following the transition. In this, it most closely resembles Yarmouth I (Figure 3). The Eemian and Yarmouth's II and III both feature a short-lived temperature spike from 2.5 to $4{ }^{\circ} \mathrm{C}$ that lasts between 5,000 to 9,000 years after the start of the interglacial transition. These are analogues to the Holocene Thermal Maximum, and can be considered interglacial thermal maxima. A typical interglacial thermal maximum lasts 3,000 to 5,000 years; the Holocene Thermal Maximum in particular is smaller in both intensity and duration (Figure 3). EPICA and Vostok exhibit different estimates for the interglacial thermal maximum associated with Yarmouth II; data from EPICA suggest it closely parallels the Eemian in timing, while Vostok suggests it 2,500 years later (Figure 3).

Interglacial transitions lasts between 5,000 to 6,000 years, with the exception of Yarmouth II from the Vostok record. Interglacial periods themselves last from 10,000 to 30,000 years following their transition. 


\section{Discussion}

The Holocene, relative to past interglacial periods, is moderate in magnitude. It is neither the hottest nor the coldest interglacial transition. The Eemian period presented a far larger rise in temperature, which was sustained throughout the duration of the interglacial period. On the other extreme, the Yarmouth III was a shorter and overall colder interglacial. The majority of climatic events in the Holocene interglacial transition can be explained by a generalized loess curve derived from the four preceding interglacials (Figure 4). The Holocene Thermal Maximum/ Altithermal period, is comparatively colder than other interglacials based on the loess model (Figure 4). Data from Vostok indicates that the late Holocene was within variability of the generalized interglacial, while data from EPICA predicts slightly colder temperatures in comparison. No evidence is found for any climatic perturbation that exceeds past interglacial variation; this includes the Younger Dryas period.

Interestingly, the Holocene interglacial transition bears a strong resemblance to Yarmouth III in that an early reversal occurs during the transition (Figure 3). However, the Yarmouth III event both begins colder and eventually leads to a warmer temperatures than the Younger Dryas. The occurrence of such an event in another interglacial would be predicted by the hypothesis that freshwater glacial melt affected the Gulf Stream (Broecker 2006). It would suggest that a comet impact is not necessary to cause a short-lived climatic reversal, unless Yarmouth III was the product of a similarly-timed extraterrestrial collision.

The comet impact hypothesis would predict that climatic disruption at 12,700 cal yr BP was more severe than other interglacials (Firestone et al. 2007; Kennett et al. 2008; Wittke et al. 2013). While the Holocene is just outside the span of the loess model, there is no punctuated climatic change that merits an extra-terrestrial explanation. One could argue that the cooler temperatures of the Altithermal compared to previous interglacials was the cause of the extinction, however there are 
two problems with this. First, Yarmouth III was still colder than the Holocene at this time (Figure 3).

Second, most arguments for climate-based extinction highlight high temperatures and aridity; these data would suggest the opposite.

This analysis find no evidence to support the alternative hypothesis, that the Holocene was a unique interglacial. It also highlights why it is critical to compare paleoclimatic data to previous interglacials to test climatic extinction hypotheses. The variation in the current interglacial and previous glacial are not sufficient in and of themselves to establish that climatic conditions were unique.

The sweeping nature of megafaunal extinctions across multiple taxa and ecosystems suggests a disruptive cause relative to the evolutionary history of these organisms; climate during the Holocene interglacial transition was not that disruptive event. Most of the features of the Holocene can be directly modeled from previous interglacials, none of which saw mass extinctions of largebodied mammalian taxa.

\section{Conclusion}

The Holocene interglacial and its transition lack any extreme temperature fluctuations compared to past interglacials; most of its variation can be modeled based on past interglacials. The Younger Dryas has a close analogue in Yarmouth III, and is likely part of a systematic freshwater influx to the North Atlantic due to glacial melt. There is no evidence to suggest that a unique climatic event in the Holocene interglacial or its transition put unique stress on megafauna taxa compared to previous interglacials, and therefore there is no evidence to support climate-based models of megafaunal extinction. 


\section{References}

Abe-Ouchi, A., Saito, F., Kawamura, K., Raymo, M.E., Okuno, J., Takahashi, K., Blatter, H. 2013. Insolation-driven 100,000-year glacial cycles and hysteresis of ice-sheet volume. Nature 500: 190-193. doi:10.1038/nature12374

Alley, R.B., Mayewski, P.A., Sowers, T., Stuiver, M., Taylor, K.C., Clark, P.U. 1997. Holocene climatic instability: A prominent, widespread event 8200 yr ago. Geology 25(6): 483-486

Alley, R.B., Ágústsdóttir, A.M. 2005. The 8k event: cause and consequences of a major Holocene abrupt climate change. Quaternary Science Reviews 24: 1123-149. doi:10.1016/j.quascirev. 2004.12.004

Antevs, E. (1948). The Great Basin, with emphasis on glacial and postglacial times. University of Utah Bulletin 38, 168-19

Barnosky, A.D., Koch, P.L., Feranac, R.S., Wing, S.L., Shabel, A.B. Assessing the Causes of Late Pleistocene Extinctions on the Continents. Science 306(5693): 70-75

Barry, D, Hartigan, J.A. 1993. A Bayesian analysis for change point problems. Journal of the American Statistical Association 35(3), 309 - 319

Broecker, W.S. 2006. Was the Younger Dryas triggered by a flood? Science 312: 1146 - 1148

Clark, P.U., Pisias, N.G., Stocker, T.F., Weaver, A.J. 2002. The role of the thermohaline circulation in abrupt climate change. Nature 415: 863-869

Cooper, A., Turney, C., Hughen, K.A., Brook, B.W., McDonald, H.G., Bradshaw, C.J.A. 015. Abrupt warming events drove Late Pleistocene Holarctic megafaunal turnover. Science 349(6248): 602-606

Cuffey, K.M., Marshall, S.J. 2000. Substantial contribution to sea-level rise during the last interglacial from the Greenland ice sheet. Nature 404: 591-594

Dokken, T.M., Jansen, E. 1999. Rapid changes in the mechanism of ocean convection during the last glacial period. Nature 401: 458-461

Dutton, A., Lambeck, K. 2012. Ice Volume and Sea Level During the Last Interglacial. Science 337: 216-219. DOI: 10.1126/science.1205749

EPICA Community Members. 2004. Eight glacial cycles from an Antarctic ice core. Nature 429: 623-628. doi:10.1038/nature02599

Erdman, C, Emerson, J.W. 2007. bcp: An R package for performing a bayesian analysis of change point problems. Journal of Statistical Software 23(3): 1 - 13

Faith, J.T., Surovell, T.A. 2009. Synchronous extinction of North America's Pleistocene mammals. PNAS 106(49): 20641-20645 
Faith, J.T. 2011. Late Pleistocene climate change, nutrient cycling, and the megafaunal extinctions in North America. Quaternary Science Reviews 30: 1675-1680. doi:10.1016/j.quascirev.

2011.03 .011

Fawcett, P.J., Werne, J.P., Anderson, R.S., Heikoop, J.M., Brown, E.T., Berke, M.A., Smith, S.J., Goff, F., Donohoo-Hurley, L., Cisneros-Dozal, L.M., Schouten, S., Sinninghe Damsté, J.S., Huang, Y., Toney, J., Fessenden, J., WoldGabriel, G., Atudorei, V., Geissman, J.W., Allen, C.D. 2011. Extended megadroughts in the southwestern United States during Pleistocene interglacials. Nature 470: 518-521

Firestone, R.B., West, A., Kennet, J.P., Becker, L., Bunch, T.E., Revay, Z.S., Schultz, P.H., Belgya, T., Kennet, D.J., Erlandson, J.M., Dickerson, O.J., Goodyear, A.C., Harris, R.S., Howard, G.A., Kloosterman, J.B., Lechler, P., Mayewski, P.A., Montgomery, J., Poreda, R., Darrah, T., Que Hee, S.S., Smith, A.R., Stich, A., Topping, W., Wittke, J.H., Wolbach, W.S. 2007. Evidence for an extraterrestrial impact 12,900 years ago that contributed to the megafaunal extinctions and the Younger Dryas cooling. PNAS 104(41): 16016-16021

Firestone, R.B., West, A., Revay, Z.S., Hagstrum J.T., Belgya, T., Que Hee, S.S., Smith, A.R. 2011. Analysis of the Younger Dryas Impact Layer. Lawrence Berkeley National Laboratory. https:// escholarship.org/uc/item/03q2r98x

French, B.V., Koeberl, C. 2010. The convincing identification of terrestrial meteorite impact structures: What works, what doesn't, and why. Earth-Science Reviews 98: 123-170

Hallberg, G.R, Wollenhaupt, N.C. and Wickham, J.T. 1980. Pre- Wisconsinan stratigraphy in southeast lowa. lowa Geological Survey Technical Information Series 11: 1-110.

Hallberg, G.R. 1986. Pre-Wisconsin glacial stratigraphy of the Central Plains region in lowa, Nebraska, Kansas, and Missouri, Quaternary Science Reviews (5): 11-15. doi: 10.1016/0277-3791(86)90169-1

Holliday, V., Surovell, T., Johnson, E. 2016. A Blind Test of the Younger Dryas Impact Hypothesis PLoS One 11(7): e0155470. doi:10.1371/journal.pone.0155470

Hubbe, A., Hubbe, M., Karmann, I., Cruz, F.W., Neves, W.A. 2013. Insights into Holocene megafauna survival and extinction in southeastern Brazil from new AMS ${ }^{14} \mathrm{C}$ dates. Quaternary Research 79: 152-157. doi:10.1016/j.yqres.2012.11.009

Israde-Alcántaram, I., Bischoff, J.L., Domínguez-Vázquez, G., Li, H.G., Bunch, T.E., Wittke, J.H., Weaver, J.C., Firestone, R.B., West, A., Kennet, J.P., Mercek, C., Xie, S., Richman, E.K., Kinzie, C.R., Wolbach, W.S. 2012. Evidence from central Mexico supporting the Younger Dryas extraterrestrial impact hypothesis. PNAS: E738-E747

Iwase, A., Hashizume, J., Izuho, M., Takahashi, K, Sato, H. 2012. Timing of megafaunal extinction in the late Late Pleistocene on the Japanese. Quaternary International 255: 114-124. doi:10.1016/ j.quaint.2011.03.029

Kaplan, M.R., Wolfe, A.P. 2006. Spatial and temporal variability of Holocene temperature in the North Atlantic region. Quaternary Research 65: 223-231 
Kaspar, F., Kühl, N., Cubasch, U., Litt, T. 2005. A model-data comparison of European temperatures in the Eemian interglacial. Geophysical Research Letters 32: L11703. doi: 10.1029/2005GL022456

Kawamura, K., Parrenin, F., Lisiecki, L., Uemura, R., Vimeux, F., Severinghaus, J.P., Hutterli, M.A., Nakazawa, T., Aoki, S., Jouzel, J., Raymo, M.E., Matsumoto, K., Nakata, H., Motoyama, H., Fujita, S., Goto-Azuma, K., Fujii, Y., Watanabe, O. 2007. Northern Hemisphere forcing of climatic cycles in Antarctica over the past 360,000 years. Nature 448: 912-916. doi:10.1038/nature06015

Keigwin, L.D., Jones, G.A., Lehman, S.J., Boyle, E.A. 1991. Deglacial Meltwater Discharge, North Atlantic Deep Circulation, and Abrupt Climate Change. Journal of Geophysical Research 96(C9): 16811-16826

Kennett, D.J., Kennett, J.P., West, G.J., Erlandson, J.M., Johnson, J.R., Hendy, I.L., West, A., Culleton, B.J., Jones, T.L., Stafford, T.W. 2008. Wildfire and abrupt ecosystem disruption on California's Northern Channel Islands at the Ållerød-Younger Dryas boundary (13.0-12.9 ka). Quaternary Science Reviews 27: 2530-2545. doi:10.1016/j.quascirev.2008.09.006

Kennett, D.J., Kennett, J.P., West, A., Mercer, C., Que Hee, S.S., Bement, L., Bunch, T.E., Sellers, M., Wolbach, W.S. 2009. Nanodiamonds in the Younger Dryas Boundary Sediment Layer. Science 323(5910): 94

Koch, P.L., Barnosky, A.D. 2006. Late Quaternary extinctions: state of the debate. Annu. Rev. Ecol. Evol. Syst. 37:215-250

Kopp, R.E., Simons, F.J., Mitrovica, J.X., Maloof, A.C., Oppenheimer, M. 2009. Probabilistic assessment of sea level during the last interglacial stage. Nature 462: 863-867. doi:10.1038/ nature08686

Liu, Z., Otto-Bliesner, B.L., He, F., Brady, E.C., Tomas, R., Clark, P.U., Carlson, A.E., Lynch-Stieglitz, J., Curry, W., Brook, E., Erickson, D., Jacob, R., Kutzbach, J., Cheng, J. 2009. Transient Simulation of Last Deglaciation with a New Mechanism for Bølling-Allerød Warming. Science 325: 310-314. DOI: $10.1126 /$ science. 1171041

Mahaney, W.C., Kalm, V., Krinsley, D.H., Tricart, P., Schwartz, S., Dohm, J., Kim, K.J., Kapran, B., Milner, M.W., Beukens, R., Boccia, S., Hancock, R.G.V., Hart, K.M., Kelleher, B. 2010. Evidence from the northwestern Venezuelan Andes for extraterrestrial impact: The black mat enigma. Geomorphology 116: 48-57

Mann, D.H., Groves, P., Reanier, R.E., Gaglioti, B.V., Kunz, M.L., Shapiro, B. 2015. Life and extinction of megafauna in the ice-age Arctic. PNAS 112(46): 14301-14306. doi:10.1073/pnas. 1516573112

McCabe, A.M., Clark, P.U. 1998. Ice-sheet variability around the North Atlantic Ocean during the last deglaciation. Nature 392: 373-377

McKay, N.P., Overpeck, J.T., Otto-Bliesner, B.L. 2011. The role of ocean thermal expansion in Last Interglacial sea level rise. Geophysical Research Letters 38: L14605. doi:10.1029/2011GL048280 
McManus, J.F., Francois, R., Gherardi, J.M., Keigwin, L.D., Brown-Leger, S. 2004. Collapse and rapid resumption of Atlantic meridional circulation linked to deglacial climate changes. Nature 428: $834-837$

Metcalfe, J.Z., Longstaffe, F.J., Ballenger, J.A.M., Vance Haynes, C. 2011. Isotopic paleoecology of Clovis mammoths from Arizona. PNAS 108(44): 17916-17920. doi:10.1073/pnas.1113881108

Nadachowski, A., Lipecki, G., Wojtal, P., Miękina, B. 2011. Radiocarbon chronology of woolly mammoth (Mammuthus primigenius) from Poland. Quaternary International 245: 186-192. doi: 10.1016/j.quaint.2011.03.011

NEEM community members. 2013. Eemian interglacial reconstructed from a Greenland folded ice core. Nature 493: 489-494. doi:10.1038/nature11789

Otto-Bliesner, B.L., Marshall, S.J., Overpeck, J.T., Miller, G.H., Hu, A., CAPE Last Interglacial Project Members. 2006. Simulating Arctic Climate Warmth and Icefield Retreat in the Last Interglaciation. Science 311: 1751-1753

Petaev, M.I., Huang, S., Jacobsen, S.B., Zindler, A. 2013. Large Pt anomaly in the Greenland ice core points) to a cataclysm at the onset of Younger Dryas. PNAS 110(32): 12917-12920

Petit, J.R,. Jouzel, J., Raynaud, D., Barkov, N.I., Barnola, J.M., Basile, I., Bender, M., Chappellaz, J., Davis, M., Delaygue, G., Delmotte, M., Kotlyakov, V.M., Legrand, M., Lipenkov, V.Y., Lorius, C., Pépin, L., Ritz, C., Saltzman, E., Stievenard, M. 1999. Climate and atmospheric history of the past 420,000 years from the Vostok ice core, Antarctica. Nature 399: 429-436. doi:10.1038/20859

Pigati, J.S., Latorre, C., Rech, J.A., Betancourt, J.L., Martínez, K.E., Budahn, J.R. 2012. PNAS 109(19): 7208-7212

Polyak, V.J., Asmerom, Y., Burns, S.J., Lachniet, M.S. 2012. Climatic backdrop to the terminal Pleistocene extinction of North American mammals. Geology 40(11): 1023-1026

Richerson, P.J., Boyd, R., Bettinger, R.L. 2001. Was agriculture impossible during the Pleistocene but mandatory during the Holocene? A climate change hypothesis. American Antiquity 66(3): 387 $-411$

Rühlemann, C., Mulitza, S., Müller, P.J., Wefer, G., Zahn, R. 1999. Warming of the tropical Atlantic Ocean and slowdown of thermohaline circulation during the last deglaciation. Nature 402: $511-514$

Sandom, C., Faurby, S., Sandel, B., Svenning, J.C. 2014. Global late Quaternary megafauna extinctions linked to humans, not climate change. Proceedings of the Royal Society B 281: 20133254. doi:10.1098/rspb.2013.3254

Sirocko, F., Seelos, K., Schaber, K., Rein, B., Dreher, F., Diehl, M., Lehne, R., Jäger, K., Krbetschek, M., Degering, D. 2005. A late Eemian aridity pulse in central Europe during the last glacial inception. Nature 436: 833-836. doi:10.1038/nature03905 
Surovell, T.A., Holliday, V.T., Gingerich, J.A.M., Ketron, C., Haynes, C.V., Hilman, I., Wagner, D.P., Johnson, E., Claeys, P. 2009. An independent evaluation of the Younger Dryas extraterrestrial impact hypothesis. PNAS 106(43): 18155-18158

Stuart, A.J., Lister, A.M. 2012. Extinction chronology of the woolly rhinoceros Coelodonta antiquitatis in the context of late Quaternary megafaunal extinctions in northern Eurasia. Quaternary Science Reviews 51: 1-17. doi:10.1016/j.quascirev.2012.06.007

Ukkonen, P., Aaris-Sørensen, K., Arppe, L., Clark, P.U., Daugnora, L., Lister, A.M., Lõugas, L., Seppä, H., Sommer, R.S., Stuart, A.J., Wojtal, P., Zupinš, I. 2011. Woolly mammoth (Mammuthus primigenius Blum.) and its environment in northern Europe during the last glaciation. Quaternary Science Reviews 30: 693-712. doi:10.1016/j.quascirev.2010.12.017

von Kolfschoten, T. 2000. The Eemian mammal fauna of central Europe. Geologie en Mijnouw / Netherlands Journal of Geosciences 79(2/3): 269-281

Willerslev, E., Cappellini, E., Boomsma, W., Nielson, R., Hebsgaard, M.B., Brand, T.B., Hofreiter, M., Bunce, M., Poinar, H.N., Dahl-Jensen, D., Johnsen, S., Steffensen, J.P., Bennike, O., Schwenninger, J.L., Nathan, R., Armitage, S., de Hoog, C.J., Alfimov, V., Christl, M., Beer, J., Muschler, M., Barker, J., Sharp, M., Penkmen, K.E.H., Haile, J., Taberlet, P,. Gilbert, M.T.P., Casoli, A., Campani, E., Collins, M.J. 2007. Ancient Biomolecules from Deep Ice Cores Reveal a Forested Southern Greenland. Science 317: 111-114. DOI: 10.1126/science.1141758

Wittke, J.H., Weaver, J.C., Buncha, T.E., Kennett, J.P., Kennett, D.J., Moore, A.M.T., Hillman, G.C., Tankersley, K.B., Goodyear, A.C., Moore, C.R., Daniel, I.R., Rayk, J.H., Lopinot, N.H., Ferrarol, D., Israde-Alcántaram, I., Bischoff, J.L., DeCarlio, P.S. Hermes, R.E., Kloosterman, J.B., Revayr, Z., Howards, G.A., Kimbel, D.R., Kletetschklau, G., Nabeleku, L., Lipo, C.P., Sakai, S., West, A., Firestone, R.B. 2013. Evidence for deposition of 10 million tonnes of impact spherules across four continents 12,800 y ago. PNAS E2088-E2097 